\title{
PARIWISATA DALAM TINJAUAN EKONOMI SYARIAH
}

\author{
Muhajirin \\ Staf Pengajar dan Dosen Tetap STAI Al-Hamidiyah Jakarta \\ ibnusyahrustany@gmail.com \\ Received: 31-03-2018, Accepted: 23-05 2018, Published: 01-06-18
}

\begin{abstract}
The purpose of this study is to know the legal view of Sharia Economics on the existence of tourism activities from various perspectives, both Al-Qur'an, Tafsir, Hadith, Philosophy of Islamic Law, Islamic Law, Review of Sharia Economics and opinion of Muslim scholars. Approach method used is: First, Historical approach (Historical approach), this approach is used to trace the context of the context behind the revelation process emerged asbab an-Nuzul theory, asbab al-Wurud, Nasikh and Mansukh Principles. Second, Analytical Approach which aims to know the meaning contained by the terms in Al-Quran and Hadith, as well as to know its application in practice. Third, Philosophical Approach (Phylosophycal Approach), the goal is to know the hikamah and philosophy of the formation of the law. Fourthly, the Comparative Approach is performed dialectically to measure the validation of arguments in the direction of each different legal provisions. This study resulted in the conclusion that travel is highly recommended by syara 'both physical tourism and spiritual tourism if the goal is an effort to get closer to the khaliq through the creation of the universe.
\end{abstract}

\begin{abstract}
Abstrak
Tujuan penelitian ini adalah untuk mengetahui pandangan hukum Ekonomi Syariah terhadap keberadaan aktivitas pariwisata dari berbagai sudut pandang, baik AlQur'an, Tafsir, Hadits, Filasafat Hukum Islam, Hukum Islam, Tinjauan Ekonomi Syariah serta tinjaun pendapat para cendikiawan muslim. Metode pendekatan yang dipakai adalah: Pertama, Pendekatan historis (Historical approach), pendekatan ini digunakan untuk menelusuri konteks konteks yang melatar belakangi proses pewahyuan muncul teori asbab an-Nuzul, asbab al-Wurud, Prinsip Nasikh dan Mansukh. Kedua, Pendekatan Analisis (Analitical Approach) yang bertujuan untuk mengetahui makna yang terkandung oleh istilah-istilah dalam Al-Quran dan Hadits, sekaligus mengetahui penerapannya dalam praktik. Ketiga, Pendekatan Filsafat (Phylosophycal Approach), tujuannya adalah untuk mengetahui hikamah dan filsafat pembentukan hukum. Keempat, Pendekatan perbandingan (Comparative Approach), dilakukan secara dialektis untuk mengukur validasi argumen yang di ketengahkan masing-masing ketentuan hukum yang berbeda. Penelitian ini menghasilkan kesimpulan bahwa
\end{abstract}


perjalanan wisata sangat dianjurkan oleh syara' baik wisata jasmani maupun wisata rohani jika tujuannya adalah upaya mendekatkan diri kepada sang khaliq melalui ciptaannya yakni alam semesta.

Keywords: Tourism, Historical approach, Analitical Approach, Phylosophycal Approach, dan Comparative Approach

\section{Pendahuluan}

Islam adalah agama yang realistis, tidak tenggelam dalam dunia khayal dan lamunan saja. Tetapi Islam berjalan bersama manusia dalam dunia kenyataan dan realistis. Islam tidak memperlakukan manusia sebagaimana malaikat yang mempunyai dua sayap, tiga, emapat dan seterusnya. Akan tetapi Islam memperlakukan mereka sebagai manusia yang butuh makan, minum, beraktifitas di pasar bahkan hiburan atau pariwisata.

Oleh karena itu Islam tidak mewajibkan umatnya agar seluruh percakapannya berupa dzikir, diamnya berarti berfikir, seluruh pendengarannya hanya kepada Al-Qur'an, dan seluruh waktu senggangnya ada di masjid. Tetapi Islam mengakui fitrah dan naluri yang diciptakan Allah pada diri mereka, yaitu Allah menciptakan mereka sebagai makhluk yang suka bergembira, bersenang-senang, tertawa, bermain dan berwiasata atau bertamasya, sebagaimana Allah S.W.T. menciptakan mereka suka makan dan minum.

Ketinggian sepiritual yang sudah dicapai oleh sebagian para sahabat Rasul S.A.W. membuat sebagian orang mengira bahwa mereka selalu serius, tekun beribadah dan senantiasa berpaling dari segala kesenangan hidup dan nuansa keindahan dunia ini. Sehingga mereka tidak mau bergembira dan tidak bermainmain, bahkan pandangan dan pemikiran mereka hanya tertuju pada akhirat dan nilai-nilai ukhrawi, jauh dari kehidupan dan kesenangan. Kemudian pertanyaan yang muncul pada kita, apakah memang demikian gambaran dari keadaan para sahabat Nabi ketika itu ?.

Kehidupan Rasulullah S.A.W. merupakan teladan yang sangat baik bagi manusia. Dalam khalawat (kesendiriannya), Nabi S.A.W. melakukan shalat dengan khusyu', menangis, berdiri lama hingga bengkak kedua kakinya. Dalam masalah kebenaran, Nabi S.A.W. tidak pernah memperdulikan seseorang demi mencari keridhaan Allah S.W.T. Akan tetapi dalam kehidupan dan hubungan dengan orang lain, Nabi S.A.W. adalah seorang manusia biasa yang mencintai kebaikan dan keindahan, wajahnya berseri-seri dan tersenyum, bermain-main dan bersenda gurau, akan tetapi tidak pernah mengatakan kecuali yang benar. ${ }^{1}$

Rasulullah S.A.W. suka terhadap kegembiraan dan apa saja yang membawa pada kegembiraan. Nabi Muhammad S.A.W. tidak menyukai kesusahan dan apa yang membawa pada kesusahan, seperti berhutang dan hal-hal yang membawa pada kepayahan, bahkan Nabi S.A.W. selalu meminta perlindungan kepada Allah

${ }^{1}$ Yusuf Qardhawi. Al-Halal wa Al-Haram fi Al-Islam. Kairo: Dar al-Ma'rifah, hlm. 335. 
S.W.T. dari keburukan, sebagaimana apa yang dipanjatkan beliau ketika berdoa:

$$
\text { أَلَلَّهُهم إِنِى أَعْوْذُ بِكَ مِنَ الْهَمِّ وَالْحُزْنِن }
$$

"Ya Allah, sesungguhnya aku berlinduk kepada-Mu dari kesusahan dan kesedihan."

Diantara gurauan yang pernah dilakukan oleh Rasulullah S.A.W. adalah sebagaimana diriwayatkan bahwa seorang wanita lanjut usia datang kepadanya seraya berkata, "Wahai Rasulullah, do'akanlah kepada Allah agar Dia memasukkan aku ke dalam surga. "Kemudian Rasulullah S.A.W. berkata kepadanya, "Wahai Ibu Fulanah, sesungguhnya surga tidak dimasuki oleh orang tua renta. "Wanita tersebut terperanjat dan menangis, karena mengira dirinya tidak akan masuk surga.

Melihat keadaan tersebut Rasulullah S.A.W. lantas menjelaskan maksudnya, bahwa orang yang sudah lanjut usia tidak akan masuk surga dalam keadaan tua renta, melainkan Allah menjadikannya sebagai gadis muda beliau. Kemudian beliau membacakan Ayat Al-Qur'an:

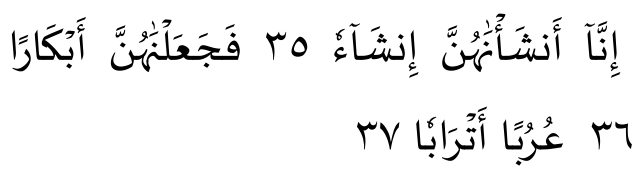

"Sesungguhnya kami menciptakan mereka (Bidadari-bidadari) dengan langsung. Dan kami jadikan mereka gadis-gadis perawan. Penuh cinta lagi sebaya umurnya." (QS. AlWaqi'ah [56]: 35-37) ${ }^{3}$

${ }^{2}$ Riwayat Imam Abu Daud dari Ghassan bin Auf (Shahih).

${ }^{3}$ Riwayat Imam At-Tirmidzi dari Aisah ra
Para sahabat Nabi S.A.W. yang mulia juga bergurau, tertawa, bermainmain dan berkata jenaka, karena mereka mengetahui kebutuhan jiwanya dan ingin memenuhi panggilan fitrah, disamping hendak memenuhi hak hatinya untuk beristirahat dan bergembira, supaya dapat melanjutkan perjalanan di jalan yang penuh keseriusan, perjalanan yang sangat panjang dan melahkan. Sahabat Ali Radhia Allah Anhu Wa Karrama Allah wajhah berkata:

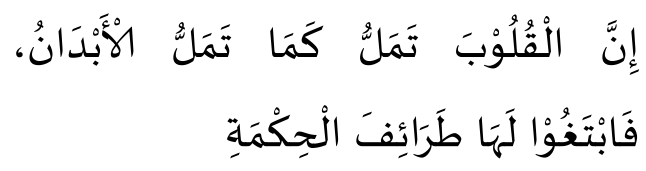

"Sesungguhnya hati bisa lesu sebagaimana badan. Oleh karena itu, carilah segi- segi kebijaksanaan demi kepentingan hati".

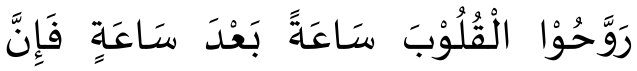

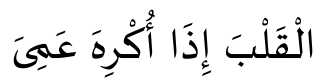

"Hiburlah hatimu sesaat demi sesaat, karena hati apabila dipaksa bisa buta".

Dari gambaran di atas, maka sangatlah penting pariwisata sebagai bentuk hiburan manusia yang fitrahnya selalu ingin memperoleh hiburan dan kesenangan. Namun yang menjadi permasalahan selanjutnya apakah setiap wisata yang kita laksanakan sesuai dengan ketentuan syariat?

\section{Pembahasan}

Mengawali kajian pariwisata dan keterkaitannya dengan ekonomi syariah, diperlukan definisi operasional tentang pariwisata. Pariwisata adalah satu sistem yang mengikut sertakan berbagai pihak (Hasan). 
dalam keterpaduan kaitan fungsional yang serasi dengan kaidah-kaidah syariah. ${ }^{4}$ Aktivitas pariwisata akan mendorong berlangsungnya dinamika mobilitas seluruh lapisan manusia, sebagai penduduk suatu tempat, untuk melakukan perjalanan sementara waktu secara sendiri-sendiri maupun berkelompok, menuju tempat lain di dalam negeri maupun di luar negeri. Mobilitas berwisata dapat menggunakan transportasi darat, laut, sungai maupun udara. Setiap wisatawan memiliki aksentuasi minat serta apresiasi tujuan yang berbeda.

Keragaman minat wisata tersebut tiadalain karenu tujuan menikmati perubahan suasana, hiburan, keunikan, keindahan alam, seni budaya, atau terkait dengan kepentingan kesehatan, pariwisata olah raga, peningkatan politik, acara soc/sial atau keagamaan, dapat juga kegiatan wisata tersebut tergabung dengan dinas maupun rekan bisnis. Kegiatan pariwisata tersebut, baik sadar maupun tidak, telah menumbuhkan persepsi dan apresiasi silang subkultural atau silang budaya. Silang budaya sebagai konsekuensi logis kegiatan pariwisata dapat meliputi lingkungan alamiahtradisional atau pada lokasi eksekutif yang tercipta karena referensi peminat pariwisata serta maksud dan tujuannya. Semua itu dapat terwujud apabila ada sarana dan prasarana, serta ada lembaga jasa yang didukung oleh iklim yang tertib dan lancar, sejuk dan nyaman, bersih, indah, aman dan penuh kenangan. Dengan demikian seluruh sistem menciptakan kenikmatan dari kehidupan yang bermakna dan multidimensional. Setiap pihak

4 Juhaya S. Praja. Ekonomi Syariah. Bandung: Pustaka Setia. hlm. 133. mempunyai aksentuasi nilai kepuasan tertentu yang bersifat psikologis, soc/sial, budaya atau ekonomi, sesuai dengan kedudukan, fungsi, peran yang bersangkutan, dalam konteks pergaulan antar manusia dan bangsa. Nilai kepuasan tersebut semakin meningkat sejalan dengan adanya implikasi dampak kemajuan ilmu dan teknologi terhadap perkembangan industry, perdagangan, transportasi, informasi dan komunikasi. Keadaan tersbut menggugah kewaspadaan terhadap kemungkinan adanya dampak negative/negatif dari pariwisata.

Secara garis besar, komponen definisi oprasional pariwisata meliputi halhal berikut ini:

1. Sistem keikutsertaan berbagai pihak dalam keterpaduan kaitan fungsional yang serasi.

2. Mendorong berlangsungnya dinamika dan mobilitas manusia.

3. Memerlukan transportasi darat, laut, sungai maupun udara.

4. Bergantung pada minat serta apresiasi tujuan dari tiap-tiap wisatawan.

5. Menimbulkan persepsi dan apresiasi silang subkultur atau silang budaya.

6. Bertujuan untuk memperoleh nilai kepuasan tertentu yang bersifat psikologi.

7. Mengandung dampak negatif.

Jika disimpulkan esensi pariwisata terdiri atas tiga unsur utama, yaitu:

1. Manusia sebagai pelaku.

2. Ruang sebagai unsur fisik.

3. Waktu. ${ }^{5}$

${ }^{5}$ Engkin Mudayana, Pariwisata Prajna Artha Buana. Pariwisata Memacu Perdamaian dan Kesejahteraan Dunia. Orasi Dies Natalis UIN 
Konsep pariwisata dalam masyarakat manckup empat unsur, yaitu: ${ }^{6}$

1. Unsur dinamis,yaitu fenomena pariwisata yang mencakup: konsep dasar, prinsip, faktor yang mempengaruhi perjalanan.

2. Unsur pelayanan, yaitu sistem pariwisata yang mencakup komponen permintaan, persediaan dan komponen penghubung.

3. Unsur fungsional, yaitu manajemen pariwisata dan latihan.

4. Unsur akibat, yaitu dampak pariwisata terhadap ekonomi, sosial, budaya dan lingkungan.

Berdasarkan definisi oprasional dan pernyataan-pernyataan tersebut, dari sudut pandang syariat Islam, aktivitas pariwisata diarahkan sesuai dengan prinsip-prinsip ta'arruf (saling mengenal), tabadul almanafi' (pertukaran manfaat) dan ta'awwun dan takaful (saling menolong dan saling menanggung resiko). Oleh karena itu, salah satu misi ilmu kepariwisataan dalam Islam adalah menyusun secara ilmiah dan sistematis upaya-upaya untuk memaksimalkan manfaat pariwisata dan meminimalkan dampak negatifnya.

\section{Bedah Tafsir}

Alam raya dan segala isinya, demikian juga teks-teks redaksi Al-Qur'an, dinamai oleh Allah S.W.T. sebagai "ayatayat Allah". Sementara ulama dalam rangka membedakannya, menamai ayat yang pertama sebagai ayat Kawniyah dan yang kedua sebagai ayat Qur'aniyah. Secara harfiyah, ayat berarti tanda dalam

Bandung ke-33 dan Wisuda ke-11, Senin, 17 April 1995 di Hotel Horison Bandung.

${ }^{6}$ Hudman dan Hawkins. hlm. 89. arti rambu-rambu perjalanan menuju Allah S.W.T., atau bukti-bukti kekuasaan dan keesaan Allah S.W.T. Tanda tersebut tidak dapat difungsikan dengan baik sebagai tanda kecuali apabila didengar atau dipandang, baik dengan mata hati maupun dengan mata kepala sebagai salah satu panca indra.

Karena itu, dalam Al-Qur'an ditemukan sekian banyak perintah-perintah Allah yang berkaitan dengan pemungsian tanda-tanda tersebut. Khusus yang menyangkut pandangan, tidak kurang dari tujuh ayat yang mengaitkan secara langsung perintah memandang itu dengan perjalanan, seperti ayat; Berjalanlah di bumi dan lihatlah..... Bahkan al-saihun (wisatawan) yang melakukan perjalanan dalam rangka memperoleh ibrah (pelajaran dan pengajaran), dipuji oleh Al-Qur'an berbarengan dengan pujiannya kepada orang-orang yang bertaubat, mengabdi, memuji Allah, rukuk dan sujud, memerintahkan kepada kebaikan dan mencegah kemungkaran serta memelihara ketetapan-ketetapan Allah (QS. At-Taubah [9]: 112).

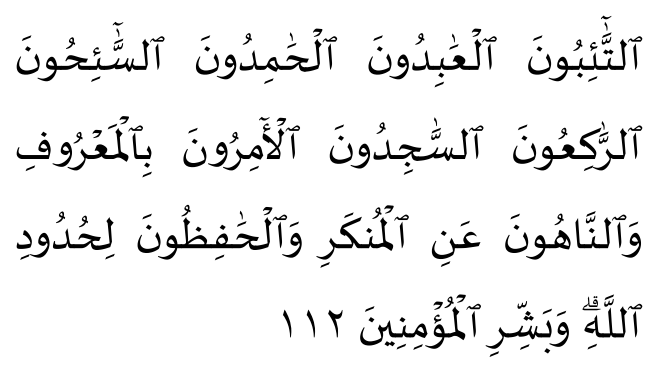

"Mereka itu adalah orang-orang yang bertaubat, yang beribadat, yang memuji, yang melawat, yang ruku', yang sujud, yang menyuruh berbuat ma'ruf dan mencegah berbuat Munkar dan yang memelihara hukum-hukum Allah. 
dan gembirakanlah orang-orang mukmin itu." (QS. At-Taubah [9]: 112).

Kata al-saihun terambil dari kata siyahah yang secara populer diartikan wisata. Kata ini mengandung arti penyebaran. Karena itu, dari kata ters

ebut dibentuk kata sahat yang berarti lapangan yang luas. ${ }^{7}$ Sementara ulama ingin membatasi pengertian kata tersebut bahkan mengartikannya dalam ayat di atas dengan pengertian metaphor seperti puasa. ${ }^{8}$ Tetapi apa yang mereka lakukan itu, dinilai tidak mempunyai dasar yang kuat.

Muhammad Jamaluddin Al-Qasimiy (1866 - 1914) menguraikan dalam Tafsirnya bahwa siyahah adalah perjalanan wisata, karena menurutnya, cukup banyak bukti dan indikator ayat Al-Qur'an sebagai berikut: "Saya telah menemukan sekian banyak pakar yang berpendapat bahwa kitab suci memerintahkan agar mengorbankan sebagian dari (masa) hidupnya untuk melakukan wisata dan perjalanan agar ia dapat menemukan peninggalan-peninggalan lama, mengetahui kabar berita umat terdahulu, agar semua itu dapat menjadi pelajaran dan ibarat yang dengannya dapat diketuk dengan keras otak-otak yang beku". 9

Perlu digarisbawahi bahwa pendapat di atas menekankan perlunya wisata walaupun dalam bentuk pengorbanan. Ini berarti bahwa perjalanan yang tidak

7 Al-Raghib Al-Asfahany. Mu'jam AlMufradat Fi Gharib Al-Qur'an. Bairut: Daar AlFikr. t.t. hlm. 253.

8 Al-Qurthuby, Tafsir Ahkam Al-Qur'an. Daar Al-Katib Al-Aroby, Kairo, Juz VIII, hlm. 269.

9 Muhammad Jamaluddin Al-Qasimiy. Mahasin At-Ta'wil. Kairo: Al-Halabiy. Jus VIII, h. 3276 mengandung pengorbanan lebih dianjurkan lagi, dan bahwa tujuan wisata antara lain adalah untuk memperluas wawasan, atau apa yang diistilahkan Al-Qasimiy," diketuk dengan keras otak-otak yang beku". Memang sah saja, jika kata saih di atas diterjemahkan dengan arti "wisatawan", karena kata itu juga berarti air yang terus menerus mengalir di tempat yang luas dan tidak pernah membeku.

Muhammad Rasyid Ridha (18651935) menulis: "Kelompok sufi mengkhusukan arti al-saihun yang dipuji itu adalah mereka yang melakukan perjalanan di muka bumi dalam rangka mendidik kehendak dan memperluas jiwa mereka". ${ }^{10}$

Mufassir terkenal, Imam Fakhruddin Ar-Raziy (1149 - 1209), menulis: "Perjalanan wisata mempunyai dampak yang sangat besar dalam rangka menyempurnakan jiwa manusia. Karena dengan perjalanan itu, ia mungkin menemui atau mengalami kesulitan dan kesukaran, ketika itu ia mendidik jiwanya untuk bersabar. Mungkin juga ia menemukan orang yang terkemuka, sehingga ia dapat memperoleh dari mereka hal-hal yang tidak dimilikinya. Selain itu, ia juga dapat menyaksikan aneka ragam perbedaan ciptaan Allah S.W.T. Walhasil, perjalanan wisata mempunyai dampak yang kuat dalam kehidupan beragama seseorang."11

At-Thabthaba'iy, ulama Syiah kontemporer, juga memahami kata saihun pada surat Al-Taubah Ayat 112 itu dengan

10 Muhammad Rasyid Ridha. Tafsir AlManar. Kairo: Maktabah Al-Manar. Juz XI, hlm. 53.

11 Fakhruddin Ar-Raziy, Tafsir Al-Kabir. Bairut: Daar Al-Fikr. Juz XV, hlm. 55. 
arti perjalanan wisata. ${ }^{12}$ Dengan demikian, kita tidak mengemukakan suatu pendapat baru jika menyatakan bahwa Al-Qur'an menganjurkan perjalanan wisata.

Jangan diduga bahwa perjalanan yang dianjurkan tersebut hanya terbatas pada kaum pria. Al-Qur'an menjadikan pula salah satu ciri wanita yang baik, bahkan yang wajar menjadi pendamping Nabi S.A.W. adalah mereka yang melakukan perjalanan wisata. Kalau dalam surat Al-Taubah ayat 112 Al-Qur'an menyebutkan wisatawan pria (al-saihun), maka secara khusus dalam ayat 5 surah AlTahrim dipergunakan istilah saihat, yakni wisatawan wanita.

Dalam hal ini, menarik sekali apa yang dikatakan Al-Qasimy bahwa mereka yang membatasi wisata bagi pria,"seakanakan menganggap bahwa udara terbuka dikhususkan bagi selain wanita, atau seakan-akan mereka diciptakan kecuali untuk dikurung didalam rumah". ${ }^{13}$ Selanjutnya Al-Qasimy menulis pula bahwa Rasul sendiri seringkali mengundi siapakah diantara isteri beliau yang akan bepergian bersamanya. Hal ini menunjukkan bahwa wisata bagi kaum wanita adalah sesuatu yang dibenarkan agama.

Perjalanan mubah (yang tidak mengakibatkan dosa) dibenarkan oleh agama. Bahkan mereka yang melakukannya memperoleh keringanankeringanan dalam bidang kewajibankewajiban agama, seperti kebolehan menunda puasanya, menggabung waktu pelaksanaan shalat (jama') atau

12 Muhammad Husain At-Thabthaba'iy. Tafsir Al-Mizan. Teheran: Daar Al-Kutub AlIslamiyah. Juz XII, hlm. 5865.

${ }^{13}$ Al-Qasimiy. op cit. Juz XII, hlm. 5.856. mengurangi jumlah rakaat shalatnya (qashar). Tetapi yang terpuji dari satu perjalanan, adalah sifatnya seperti apa yang ditegaskan dalam salah satu ayat yang memerintahkan melakukan perjalanan, sebagaimana penjelasan ayat Al-Qur'an berikut ini:

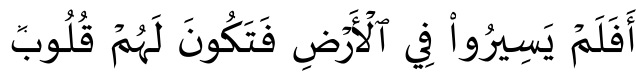

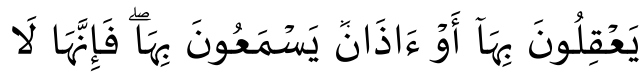

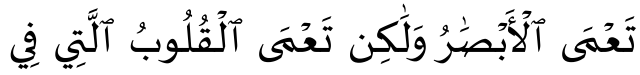

$$
\begin{aligned}
& \text { ألصيُّدُورِ }
\end{aligned}
$$

"Maka Apakah mereka tidak berjalan di muka bumi, lalu mereka mempunyai hati yang dengan itu mereka dapat memahami atau mempunyai telinga yang dengan itu mereka dapat mendengar? karena Sesungguhnya bukanlah mata itu yang buta, tetapi yang buta, ialah hati yang di dalam dada." (QS. AlHajj [22]: 46)

Di samping itu, dari wisata AlQur'an juga mengharapkan agar manusia memperoleh manfaat dari sejarah pribadi atau bangsa-bangsa, sebagaimana penjelasan dalam surat Al-Mu'min Ayat 21:

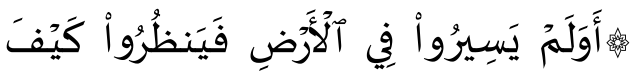

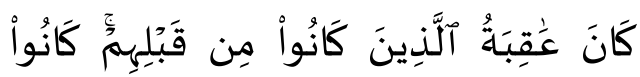

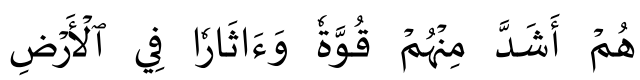

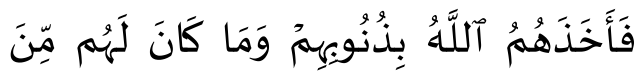

$$
\begin{aligned}
& \text { آللَّلَهِ مِن وَاقِ }
\end{aligned}
$$


sebelum mereka. mereka itu adalah lebih hebat kekuatannya daripada mereka dan (lebih banyak) bekasbekas mereka di muka bumi, Maka Allah mengazab mereka disebabkan dosa-dosa mereka. dan mereka tidak mempunyai seorang pelindung dari azab Allah." (QS. Al-Mu'min [40]:21)

Kemudian mengenal alam mini dengan segala keindahan dan seni-seninya sebagaimana diisyaratkan dalam oleh firman Allah S.W.T. dalam surat AlAnkabut [29] Ayat 20:

Artinya: Katakanlah: "Berjalanlah di (muka) bumi, Maka perhatikanlah bagaimana Allah menciptakan (manusia) dari permulaannya, kemudian Allah menjadikannya sekali lagi. Sesungguhnya Allah Maha Kuasa atas segala sesuatu." (QS. Al-Ankabut [29]: 20)

\section{Filsafat Pariwisata}

Penataan dan pengembangan pariwisata sebagai disiplin ilmu yang mandiri memerlukan kontribusi para pakar dari berbagai pihak agar membentuk citra kemandiriannya yang sesuai dengan filsafat bangsa Indonesia. Penataan dan pengembangan tersebut perlu dirancang dan ditata aspek-aspek filsafat pariwisata yang meliputi ontologi, epistologi dan aksiologinya, aspek terminology, aspek teori hukum kepariwisataan, dan dimaklumi pendidikan tinggi kepariwisataan. ${ }^{14}$

Prinsip pembangunan pariwisata diarahkan penciptaan perdamaian dunia ketika para wisatawan dari lintas negara dipertemukan oleh ragam keindahan yang diberikan Allah S.W.T. Pertemuan antar wisatawan akan memeberikan dampak secara ekonomi bagi masyarakat lokal. Jika dikelola dengan baik, akan meningkatkan pendapatan dan kesejahteraan masyarakat. Dalam Islam, prinsip ini dirumuskan dalam term ta'arruf sesuai dengan Al-Qur'an Surat Al-Hujarat [49] ayat 13:

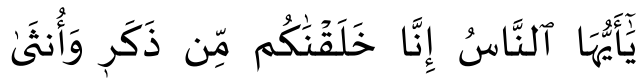

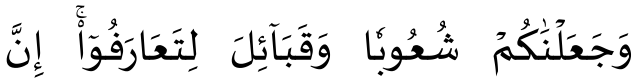

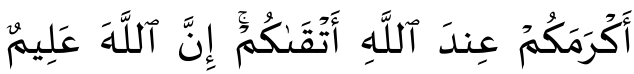

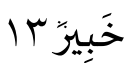

"Hai manusia, Sesungguhnya Kami menciptakan kamu dari seorang lakilaki dan seorang perempuan dan menjadikan kamu berbangsa-bangsa dan bersuku-suku supaya kamu saling kenal-mengenal. Sesungguhnya orang yang paling mulia diantara kamu disisi Allah ialah orang yang paling taqwa diantara kamu. Sesungguhnya Allah Maha mengetahui lagi Maha Mengenal." (QS. Al-Hujarat [49]: 13)

Karena aktivitas pariwisata tidak bisa berjalan secara ekslusif, industri pariwisata terkait dengan gejala internasional dan berjalan secara inklusif. Hal ini karena pariwisata adalah kegiatan yang mengeratkan sikap saling pengertian dan kerjasama antar bangsa. Meskipun mempunyai keterkaitan dengan gejala internasional, aktivitas pariwisata harus tetap berjalan dan berpegang teguh nilainilai yang dianut masyarakat. Nilai-nilai

\footnotetext{
${ }^{14}$ Hudwan \& Hawkins. hlm. 89.
} 
inilah yang menjadi penyangga dampak negatif yang dibawa oleh para wisatawan.

$$
\text { Untuk merealisasikan filsafat }
$$

pariwisata, sebagaimana telah dijelaskan, tidaklah mudah karena memerlukan tenaga-tenaga profesional. Hal tersebut karena pada satu pihak, pariwisata dituntut untuk meningkatkan persahabatan antar bangsa, dan pada pihak lain, ia dituntut untuk menanamkan cinta tanah air dan memperkukuh persatuan dan kestuan bangsa. Dengan demikian, upaya untuk merealisasikan amanat-amanat tersebut memerlukan pendidikan dan pelatihan yang memadai bagi seluruh pihak yang terlibat dalam kegiatan pariwisata. Sementara itu, pendidikan dan pelatihan di bidang pariwisata merupakan hal yang kompleks. Dengan demikian, jika konferensi PATO/WTO di Bali menganggap bahwa kegiatan pariwisata sebagai tantangan yang bersifat global yang meliputi enam tantangan. ${ }^{15}$

1. Kegiatan pariwisata yang multi disipliner.

2. Diperlukan biaya yang besar dan waktu yang panjang bagi pendidikan dan latihan di bidang pariwisata.

3. Kesulitan untuk menyelarasakan antara keterampilan yang dibutuhkan dan realitas ekonomi.

4. Kesulitan untuk menyediakan personel yang terdidik pada struktur industri pariwisata.

5. Banyaknya negara dan lembaga pendidikan yang harus mengadopsi pendekatan yang lebih profesional terhadap pendidikan dan pelatihan di bidang pariwisata.

\footnotetext{
${ }^{15}$ Robert Bently. 1994. hlm. 3-5.
}

6. Terjadinya perubahan pangsa pasar di bidang pariwisata.

Upaya untuk memecahkan berbegai permasalahan kepariwisataan di Indonesia merujuk pada filsafat dan peraturan perundang-undangan yang berlaku. Oleh karena itu, pembangunan pariwisata di Indonesia berlandaskan asas manfaat dan keseimbanagan dalam kehidupan sebagai mana diamanatkan dalam Undang-Undang No. 9 Tahun 1990 pasal 2. Pasal ini menyatakan bahwa Pembangunan objek dan daya tarik wisata bukan hanya memperhatikan nilai kehidupan ekonomisosoal dan budaya, tetapi juga memperhatikan kelestarian budaya dan kualitas lingkungan hidup, serta keberlangsungan usaha pariwisata itu sendiri. ${ }^{16}$ Oleh karena itu, pengembangan konsep pembangunan keperiwisataan meliputi tiga konsep berikut ini:

1. Konsep Konservasi, ditujukan bagi kawasan potensial yang harus tetap natural. Bagi pariwisata, perhatian terhadap guncangan daya topang lingkungan sangat besar. Secara klasik, para ahli mengunakan metode analisis daya topang lingkungan guna menyusun kebijakan berdasarkan prinsip-prinsip konservasi ini, yaitu perlindungan terhadap kondisi elemen geosfera yang potensial karena berfungsi penting bagi pariwisata dan kehidupan luas. Aplikasi ini bertolak dari pertimbangan kategorikal terpadu, yaitu antara unsurunsur rekreasi-wisata dan unsur ekologi-lingkungan.

${ }^{16}$ Misriyadi Triatmojo, Konsepsi Strategis Pembangunan Kepariwisataan yang Terlanjutkan, Serasi dengan Pelestarian Matra Lingkungan: Orasi Ilmiah Pada Dies Natalis XXX dan Wisuda SETIEPAR-AKTRIPA YAPARI- Bandung 19 Desember 1992. 
2. Konsep Restorasi merupakan penjabaran konsep konservasi. Apabila kita telaah lebih jauh, semua aspek yang terkandung dalam prosedur pengembangan kepariwisataan di Indonesia saat ini, belum sepenuhnya mengarah pada kaidah-kaidah pembanganan yang terlanjutkan. Bagi kawasan yang sudah terguncang daya topangnya, konsep detail yang baru, yang dapat memperkukuh pengembangan kepariwisataan yang berwawasan lingkungan dengan mengaplikasikan asas keseimbangan lingkungan, yang bertolak dari strategi restorasi daya topang, baik untuk perlindungan maupun perluasan.

3. Konsep Providensi merupakan tindakan preventif dalam pemanfaatan sumbersumber daya alam untuk perluasan masa mendatang. Berbeda dengan prinsip sebelumnya, upaya ini ditujukan untuk memanfaatkan lahan di kawasankawasan non-potensial, melalui aplikasi teknologi tepat guna. Adapun kawasankawasan potensial diperuntukkan bagi tahap pembangunan berikutnya, dan sebagai cadangan apabila diverifikasi produk wisata semacam ini sudah bukan merupakan metode yang tepat. Pada hakikatnya terkandung makna penghematan dan tindakan bijaksana dalam proses pengambilan keputusan untuk pembangunan yang berkelanjutan.

Dengan demikian ketiga konsep di atas menjadi pijakan dalam pembangunan dan pengembangan pariwisata di Indonesia.

\footnotetext{
Pariwisata dalam Tinjauan Ekonomi Syariah
}

Dalam kesejarahannya, pariwisata dalam tradisi Islam dimulai dari kemunculan Islam sebagai agama yang universal, yaitu ketika dikenal konsep ziyarah, yang secara harfiyah berarti berkunjung. Dari budaya ziyarah, lahir berbagai bentuk pranata social Islam yang dibimbing oleh etika dan hukumnya. Selanjutnya, lahir konsep dhiyafah, yaitu tata karma berkunjung yang mengatur etika dan tatakrama serta hokum hubungan social antara tamu (dhaif) dengan tuan rumah (mudhif). Konsep Ziyarah tersebutpun mengalami mengalami perkembangan dan melahirkan berbagai bentuknya.

Ziyarah yang kita artikan pariwisata atau tour dalam Islam, baik yang terkandung dalam Al-qur'an maupun hadits dan sejumlah pandangan ulama, mengenal pula berbagai terminology, seperti al-safar, intisyar, arrihlah dan istilah-istilah yang sekar dengan terma tersebut. Istilah safar bias kita jumpai antara lain dalam QS. Al-Baqarah [2] ayat 184:

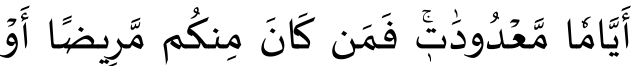

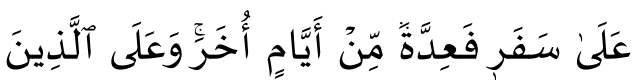

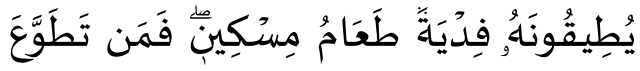

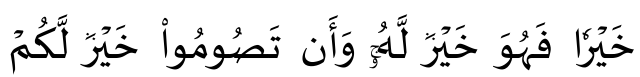

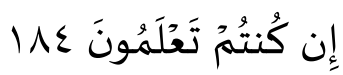


Istilah rihlah bisa kita jumpai dalam Al-Qur'an surat Quraisy [106] ayat 2:

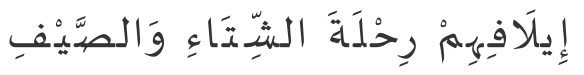

“(yaitu) kebiasaan mereka bepergian pada musim dingin dan musim panas.”

Rihlah dalam ayat ini mengandung pengertian perjalanan bisnis. Yaitu orang-orang Quraisy mempunyai kebiasaan pada musim dingin dan musim panas. Perjalanan yang mereka lakukan bukan sekedar untuk berpariwisata melahirkan perjalanan untuk kegiatan bisnis.

Menurut Fazrulrahman, pangsa pasar Quraisy sampai wilayah Syiria, Turki, Bulgaria, Yunani, Eropa Timur, Yaman, Oman, atau bekerjasama dengan pedagang Cina, India, singgah di pelabuhan Aden. ${ }^{17}$ Jika dilihat dari peta bisnis yang dikembangkan oleh kaum Quraisy yang begitu luas, tampak bahwa mereka mampu meletakkan prinsip-prinsip perdagangan lintas Negara atau go to global market. Mereka pergi menjadi pemain global, tidak hanya jago kandang.

Profesi yang dipilih orang-orang Quraisy sebagai seorang pebisnis dilatarbelakangi oleh kondisi Jazirah Arab yang kering, susah air, dan tidak kondusif jika menjadi petani atau peternak. Oleh karena itu, mereka lebih memilih profesi sebagai seorang pebisnis daripada profesi sebagai petani atau peternak.

Kompetensi bisnis yang dimiliki oleh orang-orang Quraisy jika dikaitkan dengan perdagangan modern saat ini, sama halnya

17 Fazlurrahman. Muhammad As Trader. London: The Muslim Trust. hlm. 3. dengan Hongkong atau Singapura, negeri yang miskin dengan sumber daya alam, tetapi mempunyai kemampuan untuk menggerakkan dan mengontrol alur ekspor di regional Asia Tenggara dan Asia Pasifik. Bagaimana dengan Indonesia yang luas salah satu pulaunya (Riau) lima puluh kali Singapura, dengan potensi ekspor dan sumber daya alam yang melimpah.? Ini adalah sebuah pelaajaran bagi kita untuk bercermin dari ayat di atas.

Adapun Istilah yang seakar dengan kata intisyar dijumpai dalam QS. AlJumu'ah [62] Ayat 10:

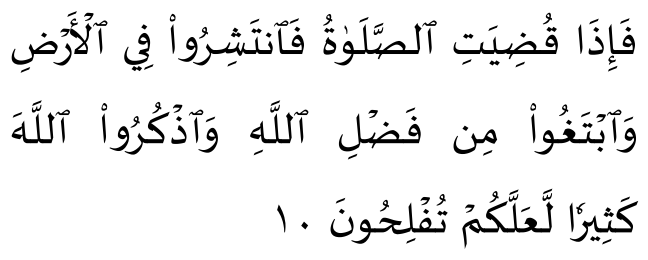

"Apabila telah ditunaikan shalat, Maka bertebaranlah kamu di muka bumi; dan carilah karunia Allah dan ingatlah Allah banyak-banyak supaya kamu beruntung." (QS. AlJumu'ah [62] ayat 10)

Menurut Abdul Mun'im, teks ayat tersebut mengandung makna bahwa, apabila kamu telah menunaikan shalat, kamu diperintahkan untuk menyebar (tafriq) keseluruh bumi, dan segera keluar dari masjid karena hal tersebut maslahat bagi kamu. Pendapat ini juga di perkuat oleh imam Al-Qurthuby yang menyebutkan, "Apabila kamu telah melaksanakan shalat, menyebarlah kamu di muka bumi untuk melakukan perniagaan dan melakukan usaha-usaha yang menyangkut kebutuhan kamu.",18

\footnotetext{
18 Al-Qurthubi. Tafsir Al-Qurthuby. Bairut: Daar Ihya al-Turats al-Aroby, Juz 18, hlm. 108.
} 
Dalam sebuah riwayat disebutkan bahwa pada suatu hari Rasulullah S.A.W. masuk ke dalam mesjid. Pada saat itu beliau bertemu dengan seorang laki-laki yang sedang duduk santai dalam waktu yang cukup lama. Kemudian Rasulullah S.A.W. bertanya kepada laki-laki tersebut, "Mengapa engkau duduk-duduk santai dalam masjid, padahal ini bukan waktunya shalat ?. Laki-laki tersebut menjawab: ini adalah kebiasaanku, ya Rasulullah. Kemudian Rasulullah memerintahkan lakilaki tersebut untuk mencari karunia Allah yang terhampar di muka bumi.,"19

Jika melihat sepirit ayat di atas, pada hakikatnya aktifitas bepergian atau aktivitas pariwisata dalam Islam sebenarnya tidak hanya untuk memenuhi kepuasan secara jasmani, tetapi harus memiliki nilai ekonomis. Jika prinsip ini diterapkan dalam perekonomian modern, akan mendorong terciptanya daya saing ekspor.

Ketika kita diperintahkan untuk bertebaran di muka bumi, itu artinya kita diperintahkan untuk bertebaran di pasar global, dan disinalah muncul daya saing ekspornya. Produk yang bisa ditawarkan dalam pasar ekspor adalah produk yang good and service. Di pasar ekspor, kita akan bertemu dengan pemain-pemain global lainnya (Cina, Taiwan, Korea, India, dan Thailand). Menurut kaidah marketing yang sederhana, kita tidak mungkin bersaing dengan para competitor global lainnya tanpa memiliki $4 \mathrm{P}$ : Product (Produk yang berkualitas), Price (harga yang menarik), Promotion (promosi yang

\footnotetext{
${ }^{19}$ Riwayat ini merupakan asbabun Nuzul turunnya surat Al-Jumu'ah ayat 10 yang dikutip oleh Abdul Mun'im Ahmad dalam kitabnya, Fathurrahman fi Tafsir Al-Qur'an.
}

intens) dan placement (Penyerahan yang tepat). Hanya dengan produk yang inovatif dan berkualitas, kita mampu merebut market share di pasar global. Produk yang inovatif dan berkualitas baru akan terjual jika harga yang ditawarkan menarik, dan melalui promosi yang intensif, sebuah produk akan dikenal. Jika sudah dikenal, konsumen akan membelinya, terlebih jika produk tersebut didukung sistem pelayanan yang prima (after sales service).

\section{Penutup}

Pariwisata merupakan aktifitas yang dianjurkan oleh syara' karena fitrah manusia dalam kehidupannya tidak meluluh melakasanakan ibadah mahdhah yang waktu, jumlah pelaksanaannya sudah ditentukan oleh syara'. Syara' juga mendorong umat Islam supaya mengenal alam sekitarnya, sehingga jika aktifitas pariwisata tersebut mempu menjadikan pelakunya lebih mengenal penciptanya, lebih menjaga lingkungan sekitarnya hal ini tentunya sangat dianjurkan karena makna ibadah bukan hanya ibadah mahdhah tetapi masuk di dalamnya ibadah ghairu mahdhah. Kegiatan pariwisata bersinggungan dengan aktifitas ekonomi, tentunya ini memerlukan penanganan yang serius supaya yang kita peroleh bukan hanya aktifitas wisata tetapi mampu membangun perekonomian yang kuat melalui aktifitas pariwisata tersebut.

\section{Daftar Pustaka}

Abdul Mun'im Ahmad. 1985. Fathurrahman fi Tafsir Al-Qur'an, Bairut: Daar Al-Fikr.

Al-Raghib Al-Asfahany. 2000. Mu'jam AlMufradat Fi Gharib Al-Qur'an. Bairut: Daar Al-Fikr. 
Qurthubi Al-. 1987. Tafsir Al-Qurthuby, Bairut: Daar Ihya al-Turats al-Aroby. Engkin Mudayana, Pariwisata Prajna Artha Buana, Pariwisata Memacu Perdamaian dan Kesejahteraan Dunia, Orasi Dies Natalis UIN Bandung ke-33 dan Wisuda ke-11, Senin, 17 April 1995 di Hotel Horison Bandung.

Fakhruddin Ar-Raziy. 1990. Tafsir AlKabir. Bairut: Daar Al-Fikr.

Fazlurrahman. 2001. Muhammad As Trader. London: The Muslim Trust.

Juhaya S. Praja. 2015. Ekonomi Syariah. Bandung: Pustaka Setia.

Misriyadi Triatmojo. Konsepsi Strategis Pembangunan Kepariwisataan yang
Terlanjutkan, Serasi dengan Pelestarian Matra Lingkungan: Orasi Ilmiah Pada Dies Natalis XXX dan Wisuda SETIEPAR-AKTRIPA YAPARI- Bandung 19 Desember 1992.

Muhammad Husain At-Thabthaba'iy. 2000. Tafsir Al-Mizan. Teheran: Daar Al-Kutub Al-Islamiyah.

Muhammad Jamaluddin Al-Qasimiy. 1998. Mahasin At-Ta'wil, Kairo: AlHalabiy.

Muhammad Rasyid Ridha. 2000. Tafsir AlManar. Kairo: Maktabah Al-Manar.

Yusuf Qardhawi. 2005. Al-Halal wa AlHaram fi Al-Islam. Kairo: Darul Ma'rifah. 